\title{
Sosialisasi Pencegahan Covid-19 yang Dikemas Dalam Poster Dan Video Edukasi 3M di Media Sosial
}

\author{
Rizky Roland Jurdil
}

\author{
Universitas Pendidikan Indonesia \\ Corresponding email: sjurdil@upi.edu
}

\begin{abstract}
Covid-19 is an outbreak from China that emerged at the end of 2019. This epidemic has become a pandemic because it has infected more than 30 countries in the world, including Indonesia. Covid-19 cases in Indonesia are always increasing day by day, because there are still many people who do not apply health protocols. Therefore, LPPM UPI Holds KKN Tematik Wave 2 with the theme "Prevention and Mitigation of the Impact of Covid-19". KKN is a form of student service to the community. In this $\mathrm{KKN}$, the executor performs his service by making a socialization program for the application of $3 \mathrm{M}$ during the adaptation period of new living habits, This program is implemented online through social media, targeting more than 117 social media users. The supporting factor in this socialization is social media which is currently very close to the community so that it can reach many social media users. The inhibiting factor in this socialization is that people are trapped in hoax news or conspiracies, so it will be difficult to provide socialization direction.
\end{abstract}

Keywords: Health Protocol; 3M; Covid-19 prevention; Socialization of the New Normal .
ABSTRAK
Covid-19 merupakan wabah dari negara tiongkok yang muncul di akhir tahun 2019, wabah ini menjadi wabah pendemi karena menjangkit lebih dari 30 negara di dunia, termasuk indonesia. Kasus covid-19 di indonesia semakin hari-semakin meningkat, dikarenakan banyaknya masyarakat yang masih tidak menerapkan protokol kesehatan. maka dari itu LPPM UPI Mengadakan KKN Tematik Gelombang 2 dengan tema "Pencegahan dan Penanggulangan Dampak Covid-19". KKN 
merupakan salah satu bentuk pengabdian mahasiswa kepada masyarakat. Pada KKN ini pelaksana melakukan pengabdianya dengan membuat suatu program sosialisasi penerapan $3 \mathrm{M}$ pada masa adaptaasi kebiasaan hidup baru, Program ini dilaksanakan secara daring melalui media sosial, dengan sasaran lebih dari 117 Pengguna media sosial. Faktor Pendukung dalam sosialisasi ini yaitu media sosial yang saat ini sangat erat dengan masyarakat, sehingga dapat menjangkau banyak pengguna media sosial. Faktor penghambat dalam sosialisasi ini yaitu masyarakat yang terjebak dalam berita hoax atau konspirasi, sehingga ini akan sulit untuk diberikan arahan sosialisasi.

Kata kunci: Protokol Kesehatan; 3M; Pencegahan Covid-19; Sosialisasi New Normal.

\section{PENDAHULUAN}

Pada akhir tahun 2019 covid-19 mewabah di negara tiongkok, akan tetapi saat ini wabah covid-19 telah menjadi wabah pendemi yang menjangkit lebih dari 30 negara di dunia, termasuk di indonesia (Suni, t.t.; Syafrida, 2020). Peningkatan kasus terinfeksi covid-19 sangatlah cepat, data dari website resmi WHO (World Health Organization) pada tanggal 30 November 2020 ada 61,869,330 kasus dari berbagai negara, 527,999 kasusnya dari Indonesia (WHO Coronavirus Disease (COVID-19) Dashboard, t.t.). Padahal sudah banyak upaya pemerintah dalam menekan peningkatan kasus tersebut, salah satunya diberlakukanya Peraturan Pemerintah Nomor 21 Tahun 2020, tentang Pembatasan Sosial Bersekala Besar (PSBB) di pertengahan bulan april 2020 upaya pemerintah dalam memutus mata rantai penyebaran covid-19 (Nasruddin \& Haq, 2020). Akan tetapi dengan diterapkanya kebijakan PSBB ini ternyata berdampak pada bidang ekonomi, bidang pendidikan, dan bidang ke agamaan (Syafrida, 2020). Banyak karyawan yang harus dirumahkan hingga di PHK, peserta didik yang harus melakukan PJJ (pembelajaran jarak jauh) dimana mereka harus sekolah dirumah melalui gadget entah itu miliknya atau milik orangtuanya, dan seluruh kegiatan ibadah keagamaan mengharuskan ibadah di rumah masing-masing. Selain itu dampak dari PSBB juga 
berpengaruh terhadap psikologi masyarakat dikarenakan masyarakat diharuskan untuk social distancing (Pradana, t.t.; Syafrida, 2020). Dalam menanggapi hal tersebut pemerintah menerapkan kebijakan baru setelah PSBB yaitu New Normal atau adaptasi kebiasaan hidup baru (COVID-19, t.t.; Pragholapati, 2020). New Normal merupkan upaya pemerintah dalam menanggulangi dampak covid-19 salah satunya dibidang ekonomi dan keagamaan. Di era new normal ini tentu masyarakat dapat beraktivitas di luar rumah akan tetapi harus menerapkan protokol kesehatan 3M yaitu memakai masker kemanapun beraktivitas, rajin untuk mencuci tangan pakai sabun, dan menjaga jarak aman dengan orang lain lebih kurang 1,5 Meter (Advice for the Public on COVID-19 - World Health Organization, t.t.). Akan tetapi yang terjadi di lapangan banyak sekali masyarakat yang belum memiliki pemahaman akan Covid-19 itu sendiri, seolah-olah covid-19 ini hanyalah sebuah konspiransi yang dibesar-besarkan (pembohongan publik), ini sangat disayangkan dengan adanya berita-berita konspirasi covid-19, masyarakat tidak lagi percaya sepenuhnya terkait keberadaan virus corona ini, sehingga mengakibatkan masyarakat yang masih abay tidak menerapkan protokol kesehatan dalam beraktivitas sehari-hari (Halim, t.t.).

Dalam membantu pemerintah, LPPM UPI melaksanakan Kuliah Kerja Nyata (KKN) Tematik Penanggulangan dan Pencegahan dampak covid-19 pada bidang Pendidikan, Kesehatan, dan Ekonomi yang dilakukan lebih dari 3000 mahasiswa. Dalam bidang kesehatan mahasiswa memberikan edukasi digital (secara daring) melalui poster yang disebar luaskan pada sosial media milik mahasiswa, aplikasi yang digunakan antara lain seperti WhatsApp, Instagram, Youtube dsb. Dalam mengikuti program ini, maka pelaksana membuat poster dan video edukasi $3 \mathrm{M}$ yang berisi bagaimana cara beraktivitas di era new normal, yaitu mencakup cara menerapkan protokol kesehatan dengan benar, dan cara beraktivitas diluar rumah agar tetap aman dari covid-19. Ini memungkinkan untuk membantu menyadarkan masyarakat terkait bahayana covid-19 dan pentingnya menggunakan protokol kesehatan dalam beraktivitas di luar rumah. Tujuan diadakannya program ini antara lain, menekan pertumbuhan kasus baru di indonesia dengan memberikan pemahaan bahwa virus corona ini memang betul adanya, dan kita perlu memperhatikan itu 
untuk menjaga diri dan menjaga keluarga yang kita sayangi dari infeksi virus corona dengan menerapkan $3 \mathrm{M}$

\section{METODE PELAKSANAAN}

Program sosialisasi pencegahan covid-19 ini dilaksanakan pada tanggal 21, 25 November, dan 2 Desember 2020 yang dilakukan secara daring melalui media sosial pribadi yaitu Instagram, WhatsApp, dan Youtube. Kegiatan secara akumulatif dilakukan selama 26 hari dimulai tanggal 21 November hingga 17 Desember, yang dilihat lebih dari 117 orang.

\section{Perencanaan Program}

Tahapan Perencanaan dalam melaksanakan program ini yaitu koordinasi bersama DPL melalui daring, Tahap selanjutnya yaitu membuat TOR (term of reference) dari poster dan video yang akan di sosialisasikan.

\section{Kegiatan Inti}

Kegiatan pertama yakni tahap pembuatan poster, antara lain mencari ilustrasi yang menarik dan bebas untuk di gunakan melalui website freepik.com, membuat desain dari gambar ilustrasi yang telah di rancang, selanjutnya memposting ke Instagram dan Whatsapp story. Kegiatan kedua yakni tahap pembuatan video, yaitu Mencari video pendukung yang bebas digunakan melalui website storyblocks.com, menggabungkan dan mengedit video tersebut satu-persatu menjadi video yang menarik, memposting ke Instagram, Youtube, dan WhatsApp story. Kegiatan ketiga yaikni mensosialisasikan juga di grup WhatsApp orang tua dari siswa kelas $2 \mathrm{SD}$

\section{Tahap Evaluasi}

Tahap evaluasi ini dalaksanakan melalui google form yang disebar melalui Instagram story dan WhatsApp story. 


\section{HASIL DAN ANALISIS}

\section{Pelaksanaan kegiatan}

Kuliah Kerja Nyata (KKN) Tematik merupakan salah satu bentuk pengabdian mahasiswa kepada masyarakat. Dalam program ini pelaksana melakukan pengabdan dengan sosialisasi pencegahan covid-19 yang dikemas berupa poster dan video untuk disebarluaskan pada media sosial. Dalam pelaksanaan ini berikut langkah yang dilakukan yaitu, membuat poster ajakan untuk menerapkan 3M seperti pada Gambar 1.

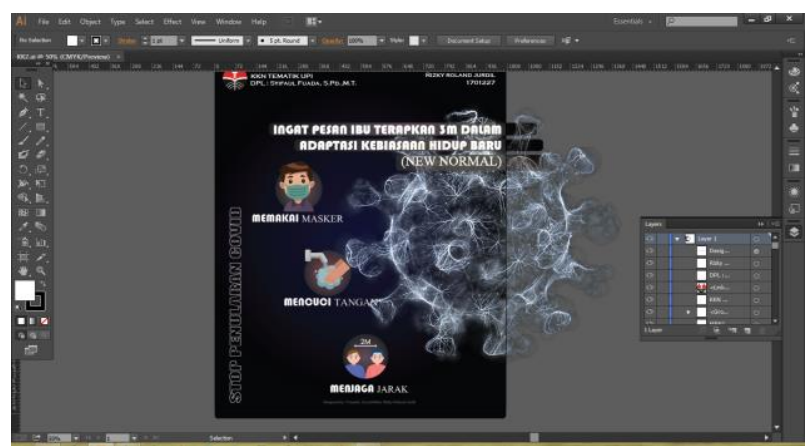

Gambar 1. Tampilan Proses Pembuatan Poster 3M

Pastikan nomor tabel, atau nomor gambar berurutan. Setelah poster jadi, selanjutnya mensosialisasikan poster ke sosial media milk pribadi pada instagram feed seperti pada Gambar 2 (a), dan mensosialisasikan juga di WhatsApp story seperti pada Gambar 2 (b).

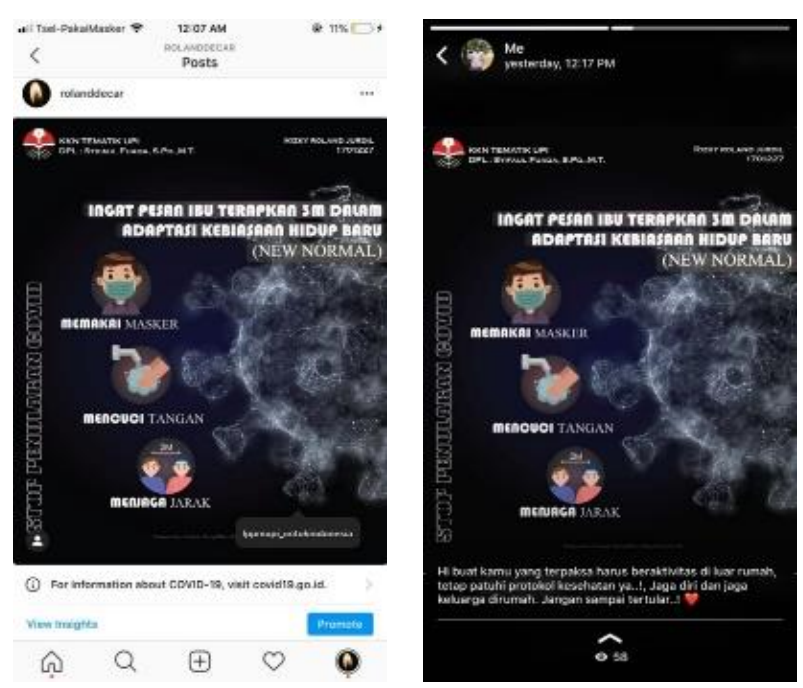


(a)

Gambar 2. Tampilan (a) feed Instagram, (b) WhatsApp Story

Selanjutnya untuk mendukung dan memberikan gambaran dalam aktivitas realisasi dari poster pada gambar 2 (a) dan gambar 2 (b) maka dibuat video sosialisasi penerapan 3M sebagai seperti pada Gambar 3.

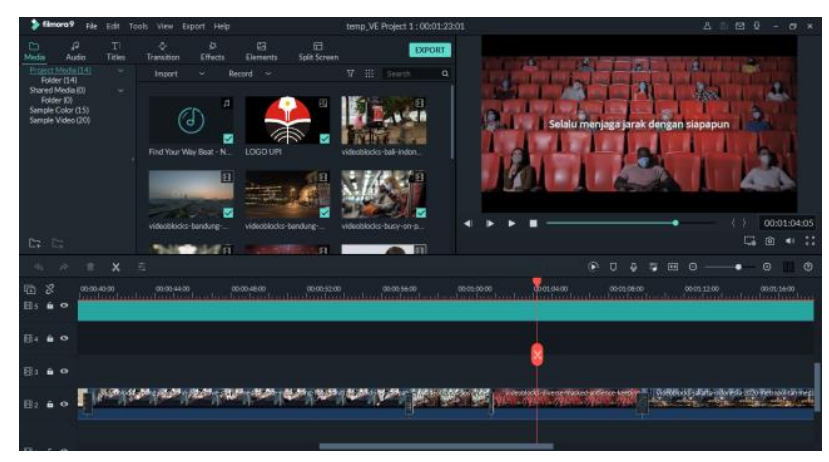

Gambar 3. Proses pembuatan video

Setelah video jadi, selanjutnya mensosialisasikan video ke sosial media milk pribadi pada IG TV (Instagram) seperti pada Gambar 4 (a), WhatsApp story seperti pada Gambar 4 (b), dan Youtube seperti pada Gambar 4(c).

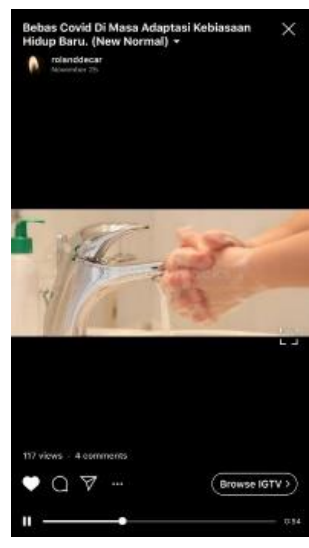

(a)

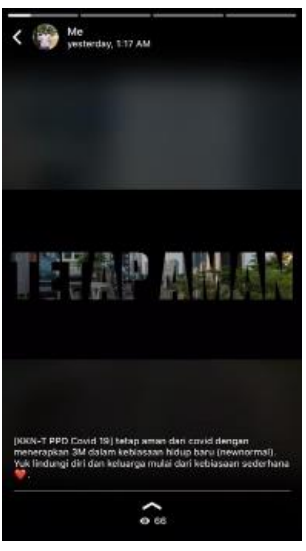

(b)

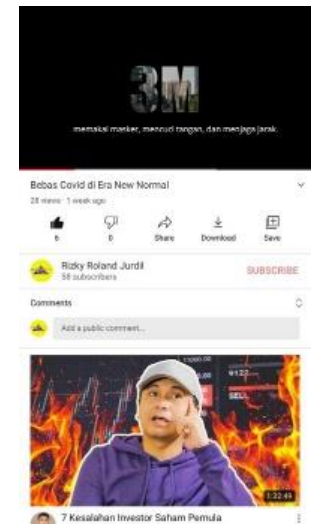

(c)

Gambar 4. Tampilan (a) IG TV (Instagram), (b) WhatsApp Story, (c) Youtube

Selanjutnya melakukan sosialisasi di WhatsApp Grup yang beranggotakan 10 orangtua dari siswa kelas 2 SD, seperti pada Gambar 5. 


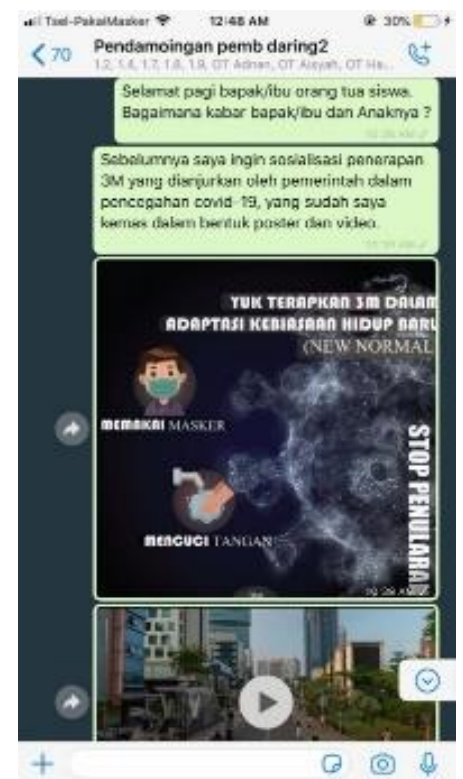

Gambar 5. Tampilan sosialisasi di WhatsApp Grup orangtua siswa

\section{Evalusi :}

Selanjutnya untuk mengetahui tanggapan dari masyarakat sasaran, maka dibuat angket online melalui google form seperti pada Gambar 6.

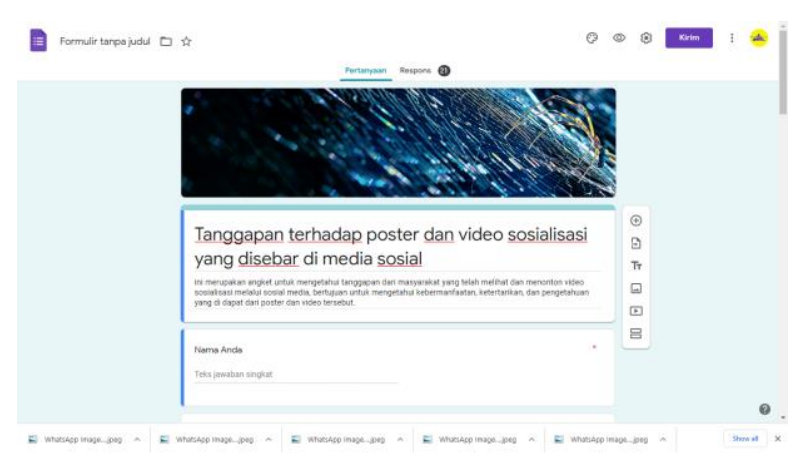

Gambar 6. Tampilan angket tanggapan

Setelah membuat angket online melalui google form, selanjutnya menyebar angket di Instagram story seperti pada Gambar 7 (a), menyebar angket di WhatsApp story seperti pada Gambar 7 (b) dan menyebar di grup WhatsApp orang tua dari siswa kelas 2 SD seperti pada gambar 7 (c). 


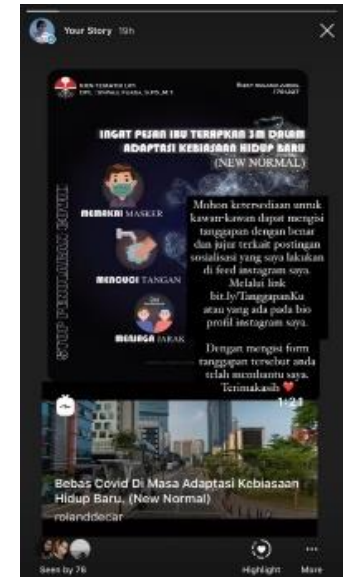

(a)

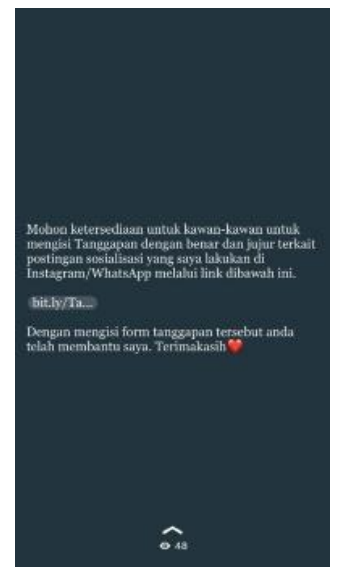

(b)

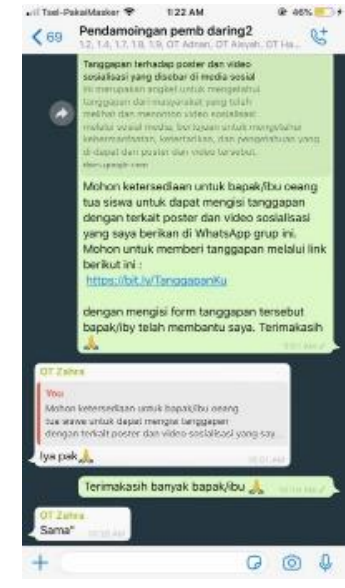

(c)

Gambar 7. Tampilan (a) Instagram Story, (b) WhatsApp Story, (c) WhatsApp Grup

\section{Data dan tanggapan yang terkumpul dalam kegiatan ini adalah sebagai berikut :}

Terdapat 21 pemberi tanggapan yang didominasi oleh umur 21 Tahun hasil data ada pada Gambar 8. Dari 21 pemberi tanggapan didominasi oleh mahasiswa, hasil data ada pada Gambar 9. Dari seluruh pemberi tanggapan, semuanya mengaku percaya bahwa Covid-19 memang ada, hasil data ada pada Gambar 10 . Dari 21 pemberi tanggapan, 14 orang mengaku bahwa sosialisasi ini sangat berguna, dan 7 orang mengaku bahwa sosialisasi ini cukup berguna. Hasil data ada pada Gambar 11. Dari 21 pemberi tanggapan, 13 orang memberi tanggapan bahwa sosialisasi ini sangat menarik, dan 7 orang memberi tanggapan bahwa sosialisasi ini cukup menarik. Hasil data ada pada Gambar 12.

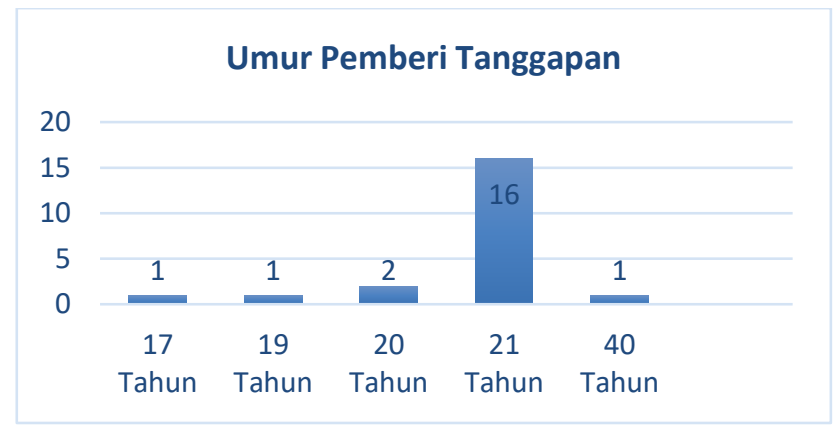

Gambar 8. Tampilan Umur Pemberi Tanggapan 


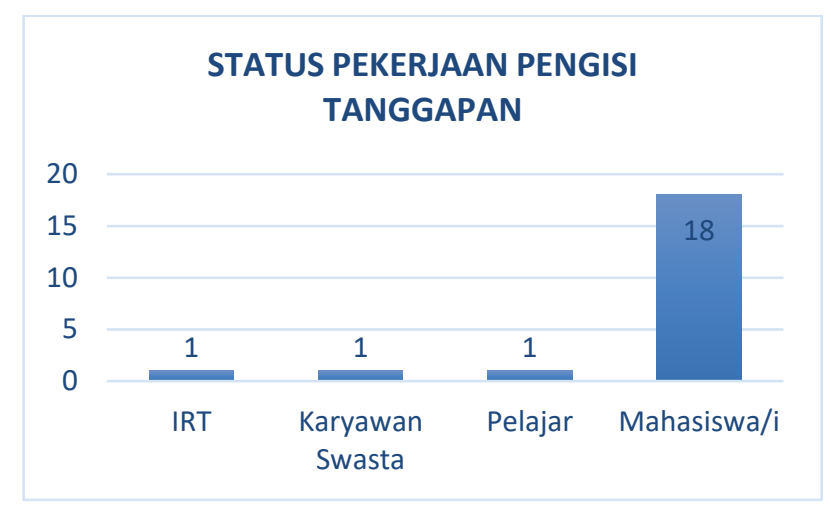

Gambar 9. Tampilan status pekerjaan dari pemberi tanggapan

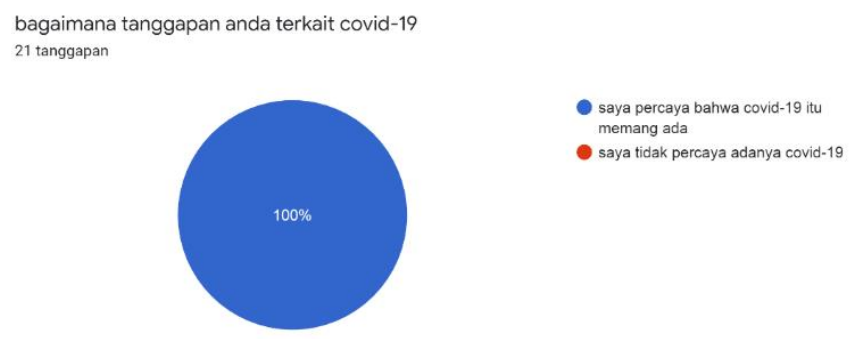

Gambar 10. Tampilan Hasil Tanggapan Terkait Covid-19

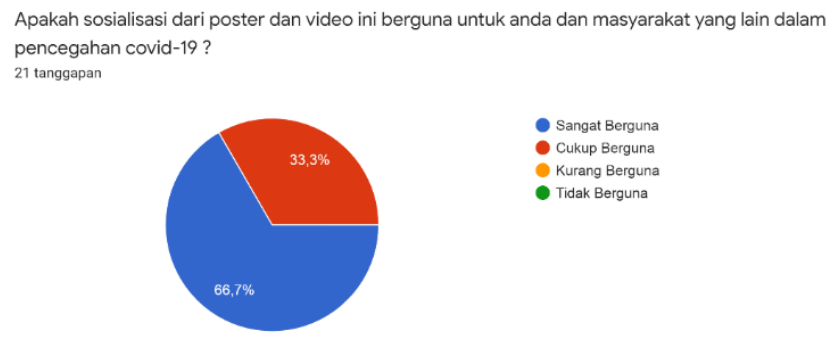

Gambar 11. Tampilan Tanggapan Terkait Persentase Kegunaan dari Sosialisasi tersebut Apakah sosialisasi ini menarik?
21 tanggapan

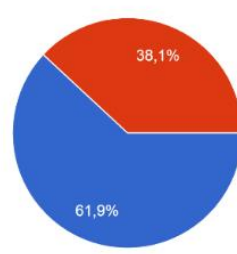

$$
\begin{aligned}
& \text { Sangat Menarik } \\
& \text { - Cukup Menarik } \\
& \text { Kurang Menarik }
\end{aligned}
$$$$
\text { - Sangat tidak menark }
$$

Gambar 12. Tampilan Tanggapan Terkait Persentase Kemenarikan dari Sosialisasi tersebut 
Tanggapan terkait poster yang telah disosisalisasikan melaui feed Instagram, WhatsApp Story, dan WhatsApp Grup orang tua siswa dapat dilihat pada Tabel 1.

Tabel 1. Tanggapan Terkait Poster yang di Sosialisasikan Melalui Instagaram/WhatsApp

\begin{tabular}{|c|c|}
\hline Peserta & Tanggapan \\
\hline AA & $\begin{array}{l}\text { Bagus,, bisa memberikan kesadaran kepada masyarakat tentang } \\
\text { edukasi pencegahan covid-19 }\end{array}$ \\
\hline $\mathrm{CR}$ & Pesan yang disampaikan sangat menarik dengan menerapkan 3M \\
\hline G & $\begin{array}{l}\text { Sangat membantu orang-orang mengingatkan untuk tetap selalu } \\
\text { menerapkan protokol } 3 \mathrm{M}\end{array}$ \\
\hline $\mathrm{RC}$ & sangat mengedukasi \\
\hline MB & $\begin{array}{l}\text { Sudah bagus, saran saya di peramai lagi dengan kata kata persuasif } \\
\text { (mengajak) }\end{array}$ \\
\hline $\mathrm{S}$ & $\begin{array}{l}\text { sangat bagus karna memberikan edukasi mengenai pencegahan dan } \\
\text { penanggulangan dampak covid } 19 \\
\text { sangat membantu untuk menyebarkan informasi, terutama bagi }\end{array}$ \\
\hline DAS & masyarakat luas \\
\hline $\mathrm{R}$ & Keren, sangat membantu untuk menyadarkan ke masyarakat \\
\hline NMRW & $\begin{array}{l}\text { Sangat membantu penyuluhan guna disiplin } 3 \mathrm{M} \\
\text { menarik ka, semoga kedepannya banyak orang yang sadar kalo }\end{array}$ \\
\hline MK & corona itu ada \\
\hline SJ & Menarik \\
\hline IGNKAJ & $\begin{array}{l}\text { Saya mengamati poster-poster yang ada di beberapa sosial media } \\
\text { dan saya selalu berupaya tetap mengikuti protokol kesehatan sesuai } \\
\text { dengan anjuran yang ada di poster. }\end{array}$ \\
\hline BA & $\begin{array}{l}\text { Simple, mudah dimengerti oleh masyarakat karena point yg } \\
\text { disampaikan tersalurkan dan sangat membantu juga berguna bagi } \\
\text { masyarakat yg melihat poster tersebut. }\end{array}$ \\
\hline SM & Sangat baik dan menarik \\
\hline FA & Sangat membantu untuk mengingat $3 \mathrm{M}$ \\
\hline EV & Baik dan mudah di mengerti \\
\hline WG & Bagus, menarik \\
\hline ALLB & Menarik \\
\hline SN & Biasa saja \\
\hline APA & Sebetulnya baik,cuma masih banyak yg menyebarkan hoax \\
\hline $\mathrm{FF}$ & $\begin{array}{l}\text { Sangat mengedukasi dan bermanfaat untuk masyarakat sehingga } \\
\text { lebih menjaga diri dari penularan covid-19 }\end{array}$ \\
\hline
\end{tabular}

Tanggapan terkait video yang telah disosisalisasikan melaui feed Instagram, WhatsApp Story, dan WhatsApp Grup orang tua siswa dapat dilihat pada Tabel 2.

Tabel 2. Tanggapan Terkait Video yang di Sosialisasikan Melalui Instagaram/WhatsApp/Youtube

\begin{tabular}{cl}
\hline Peserta & \multicolumn{1}{c}{ Tanggapan } \\
\hline AA & $\begin{array}{l}\text { Bagus,,, dengan demikian saya dapat menyadari pentingnya } \\
\text { menerapkan 3M }\end{array}$ \\
& $\begin{array}{l}\text { Menarik, mengedukasi, mudah dipahami dan tidak membosankan } \\
\text { CR }\end{array}$
\end{tabular}


Menarik, dan membantu mengingatkan untuk selalu menerapkan

G protokol 3M

RC Videonya menarik

MB Bagus ka, semoga videonya bermanfaat

S Sangat bagus karna memberikan edukasi

Informasi yang dipaparkan sangat jelas, sehingga mudah untuk

DAS dicerna

R Pas mantab

NMRW Sangat membantu membangkitkan jiwa disiplin masyarakat

MK Saya tidak menonton

SJ Menarik

Video yang disajikan sangat menarik, dan saya akan selalu

IGNKAJ berupaya menerapkan protokol kesehatan di era new normal.

Sama seperti posternya, point yg disampaikan mudah dimengerti dan sangat membantu masyarakat juga sebagai pengingat bahwa hal-hal tersebut sangat penting untuk dilakukan saat new normal

BA dan keadaan pandemi ini.

SM Baik sekali sangat kreatif

FA Bagus mengingatkan kita bahwa kita sedang tidak baik2 saja

EV Sangat menarik

WG Bagus, kratif

ALLB Sangat edukatif

SN Lumayan

APA Banyak memberi pengetahuan baru tentang new normal Sangat informatif dan bermanfaat sebagai pengetahuan bagi FF masyarakat yang melihat video tersebut.

Tanggapan terkait poster dan video yang telah disosisalisasikan melaui feed Instagram, WhatsApp Story, dan WhatsApp Grup orang tua siswa dapat dilihat pada Tabel 3.

Tabel 3. Tanggapan terkait informasi yang di dapat saat sosialisasi

\begin{tabular}{cl}
\hline Peserta & \multicolumn{1}{c}{ Tanggapan } \\
\hline AA & $\begin{array}{l}\text { Bahwa kita harus menerapkan 3M } \\
\text { Menjaga kebersihan itu penting dan kita harus sadar bahwa covid } \\
\text { ini sangat berbahaya tetapi untuk menghadapinya kita harus tetap }\end{array}$ \\
tenang dan jangan panic \\
GR & $\begin{array}{l}\text { Pesan dari poster dan videonya yaitu untuk tetap menerapkan 3M } \\
\text { dimana pun kita berada }\end{array}$ \\
RC & Jadi lebih aware jika sedang berada diluar rumah \\
MB & Menjadi tahu bagaimana pencegahan covid \\
S & Menjadi tahu apa itu 3m \\
DAS & Upaya yang dapat dilakukan untuk menghindari Covid-19 \\
R & Jangan lupa menerapkan 3 M \\
NMRW & $\begin{array}{l}\text { Pemahaman untuk lebih disiplin dalam menjaga kesehatan dan } \\
\text { tetap menerapkan 3M }\end{array}$ \\
MK & Menerapkan dalam keseharian \\
SJ & Mengerti bagaimana mencegah adanya covid 19 \\
& $\begin{array}{l}\text { Secara tidak langsung, melalui poster dan video edukasi, wawasan } \\
\text { dan pengetahuan kita menjadi bertambah dan kesadaran kita akan }\end{array}$ \\
IGNKAJ & protokol kesehatan menjadi meningkat.
\end{tabular}


Membantu mengingatkan bahwa hal-hal yg kecil sangat berarti dan membantu, karena kita tidak tau dampaknya seperti apa jadi lebih

BA baik mencegah dengan hal-hal tersebut.

SM Kebiasaan hidup baru untuk lebih menjaga kesehatan

Kita harus berhati2 dan slalu waspada dan terapkan protokol

FA kesehatan

EV Mengingatkan untuk melaksanakan 3m

WG Jadi ada inspirasi buat edit poster dan video

ALLB Jangan lupa untuk selalu menerapkan protokol kesehatan

SN Menarik

APA Lebih banyak tau cara pencegahan covid

FF Ilmu yang bermanfaat untuk mencegah virus covid-19.

\section{Faktor Pendukung dan Faktor Penghambat}

Adapun faktor pendukung dan faktor penghambat dalam melakukan program ini sebagai berikut.

1. Faktor pendukung :

Program KKN dibidang pencegahan covid-19 ini dapat terlaksana dengan bebearapa faktor pendukung antara lain, Sumber informasi yang sangat luas yang tersebar pada laman terpercaya seperti laman (who.int dan covid19.go.id), Media sosial yang dapat di akses dimanapun dan kapanpun oleh masyarakat luas pengguna media sosial, ilustrasi kekinian yang bebas pakai seperti yang ada pada website freepik.com, kemudahan mencari video stock seperti yang berada pada storyblocks.com, keterampilan menggunakan aplikasi desain seperti adobe ilustrator, dan keterampilan mengedit video seperti aplikasi filmora.

2. Faktor penghambat :

Faktor penghambat dari program ini antara lain, masyarakat yang sudah terjebak dalam berita hoax (konspirasi covid-19) sulit untuk diajak dalam melaksanakan kegiatan $3 \mathrm{M}$ ini. Faktor penghambat lainya yaitu masyarakat sudah mulai bosan dengan informasi terkait covid-19.

\section{KESIMPULAN}

Kesimpulan dari program ini yaitu masyarakat pengguna media sosial yang melihat sosialisasi ini mengaku mendapatkan informasi tentang penerapan 3M yang baik dan benar dalam aktivitas kegiatan sehari-hari dan juga berpendapat bahwa sosialisasi ini berguna bagi masyarakat luas. Dalam mencegah dan 
menanggulangi dampak covid-19 baiknya seluruh elemen bersatu dan berjuang bersama-sama, salah satu perjuanganya yaitu dengan tetap disiplin dalam protokol kesehatan, dan menjadi agen pencegahan yang dapat membawa pengaru tehadap kerabat, rekan dan orang disekitar. Adapun saran dari 21 orang yang memberikan tanggapan di google form dapat dilihat pada Tabel 4.

Tabel 4. Kritik dan Saran dari Pemberi Tanggapan

\begin{tabular}{|c|c|}
\hline Peserta & Tanggapan \\
\hline AA & $\begin{array}{l}\text { Mungkin bisa ditambah pake suara orang sedang membaca tulisan } \\
\text { yg ada dalam video }\end{array}$ \\
\hline $\mathrm{CR}$ & Lebih baik lagi agar mensosialisasikannya juga ke lapangan \\
\hline $\mathrm{G}$ & $\begin{array}{l}\text { Untuk video menurut saya alangkah baiknya untuk tidak memakan } \\
\text { waktu terlalu lama mungkin durasi } 1 \text { menit sudah sangat cukup } \\
\text { untuk sosialisasi kesehatan tentang covid-19 }\end{array}$ \\
\hline $\mathrm{RC}$ & Perbanyak videonya agar lebih banyak masyarakat yg di edukasi \\
\hline MB & Di perbanyak lg kata2 persuasifnya \\
\hline $\mathrm{S}$ & $\begin{array}{l}\text { Mungkin sedikit pesan agar bisa terus memberikan edukasi edukasi } \\
\text { seperti ini kepada masvarakat }\end{array}$ \\
\hline & Mungkin untuk kedepannya dapat disebarkan lagi secara lebih luas. \\
\hline DAS & Agar jangkauan masyarakatnya pun lebih besar \\
\hline $\mathrm{R}$ & $\begin{array}{l}\text { Kritiknya gak ada. Sarannya bikin terus meskipun kkn selesai } \\
\text { wkwkwk }\end{array}$ \\
\hline & Saran, Tetap semangat dan Optimis untuk berlaku Disiplin menuai \\
\hline NMRW & Sehat, Gencarkan terus penyuluhan Hidup \\
\hline & $\begin{array}{l}\text { Menurut saya untuk penyebaran poster dan video sebenarnya sudah } \\
\text { hal yang biasa dilakukan oleh banyak orang tetapi masih cukup }\end{array}$ \\
\hline MK & banyak orang yg tidak menerapkan 3M dalam kesehariannya \\
\hline SJ & Saran saya tidak ada \\
\hline & $\begin{array}{l}\text { Sudah sangat baik, kedepannya agar diberikan animasi animasi atau } \\
\text { gambaran lebih kritis/menegangkan sehingga masyarakat menjadi }\end{array}$ \\
\hline IGNKAJ & takut apabila melanggar protokol kesehatan. \\
\hline BA & $\begin{array}{l}\text { Sudah bagus, karena point yg terdapat dalam poster dan juga } \\
\text { videonya tersampaikan dengan cukup baik. }\end{array}$ \\
\hline SM & Sejauh ini sudah cukup baik \\
\hline FA & $\begin{array}{l}\text { Buat poster atau video lebih menarik lagi gunakan warna2 cerah } \\
\text { agar bisa menarik orang untuk melihatnya }\end{array}$ \\
\hline $\mathrm{EV}$ & Sangat menarik \\
\hline WG & Ga ada yg perlu di kritik, km terlalu sempurna wkwkwkwk \\
\hline ALLB & Mungkin lebih colorful lagi kedepannya \\
\hline SN & Di video kurang panjang \\
\hline APA & Lebih di saring lagi beritanya agar tidak banyak mengandung hoax \\
\hline $\mathrm{FF}$ & Sudah bagus. \\
\hline
\end{tabular}

Adapun rencana tindak lanjut, setelah melihat saran dan kritik dari pemberi tanggapan, pelaksana berencana untuk sebisa mungkin membuatkan poster dan video yang lebih menarik lagi, dengan waktu penayangan video yang lebih singkat 
dan mudah dipahami, serta memperluas sosialisasi pencegahan covid ke lebih banyak sosial media seperti Facebook dan Twitter.

\section{ACKNOWLEDGMENT}

Terimakasih kepada bapak dosen pembimbing lapangan Syifaul Fuada, S,Pd., M.T. yang telah membimbing pelaksana dalam melaksanakan program dan menulis artikel ini, terimakasih kepada pengguna media sosial yang telah melihat dan menonton video sosialisasi dan meluangkan waktu untuk mengisi tanggapan di google form, tidak lupa terimakasih juga kepada LPPM UPI yang telah menyelengarakan program KKN Gelombang 2.

\section{DAFTAR PUSTAKA}

Advice for the public on COVID-19 - World Health Organization. (t.t.). Diambil 30 November 2020, dari https://www.who.int/emergencies/diseases/novelcoronavirus-2019/advice-for-public

COVID-19, S. P. (t.t.). Pengantar Adaptasi Kebiasaan Baru-Pengantar | Satgas Penanganan COVID-19. covid19.go.id. Diambil 30 November 2020, dari https://covid19.go.id/edukasi/pengantar/pengantar-adaptasi-kebiasaan-baru

Halim, D. (t.t.). 6 Bulan Pandemi Covid-19: Hoaks dan Teori Konspirasi yang Memperparah Penanganan... Halaman all-Kompas.com. Diambil 30 November 2020, dari https://nasional.kompas.com/read/2020/09/05/09090921/6-bulan-pandemicovid-19-hoaks-dan-teori-konspirasi-yang-memperparah?page=all

Nasruddin, R., \& Haq, I. (2020). Pembatasan Sosial Berskala Besar (PSBB) dan Masyarakat Berpenghasilan Rendah. SALAM: Jurnal Sosial dan Budaya Syar-i, 7(7). https://doi.org/10.15408/sjsbs.v7i7.15569

Pradana, A. A. (t.t.). PENGARUH KEBIJAKAN SOCIAL DISTANCING PADA WABAH COVID-19 TERHADAP KELOMPOK RENTAN DI INDONESIA. 7.

Pragholapati, A. (2020). NEW NORMAL "INDONESIA" AFTER COVID-19 PANDEMIC [Preprint]. PsyArXiv. https://doi.org/10.31234/osf.io/7snqb 
Suni, N. S. P. (t.t.). KESIAPSIAGAAN INDONESIA MENGHADAPI POTENSI PENYEBARAN CORONA VIRUS DISEASE. 6.

Syafrida, S. (2020). Bersama Melawan Virus Covid 19 di Indonesia. SALAM: $\begin{array}{lllll}\text { Jurnal Sosial dan } & \text { Budaya }\end{array}$ https://doi.org/10.15408/sjsbs.v7i6.15325

WHO Coronavirus Disease (COVID-19) Dashboard. (t.t.). Diambil 24 Desember 2020, dari https://covid19.who.int/table 